\title{
Communication
}

\section{Gladiolus development in response to bulb treatment with different concentrations of humic acids ${ }^{1}$}

\author{
Marihus Altoé Baldotto², Lílian Estrela Borges Baldotto ${ }^{3}$
}

\begin{abstract}
Gladiolus is an ornamental species produced for cut flowers and propagated by corms. The early flowering and increase in the number of flower buds, besides the production of commercial corms are constant challenges to be addressed in the crop improvement. Commercial production of ornamentals is technologically accelerated by means of growth regulators. Among them, the auxins stand out for their key role in the adventitious rooting and cell elongation. Alternatively, the humic substances present in the organic matter also have biostimulating effect, which is very similar to the auxinic effect. Therefore, this work aimed to study the growth and development of gladiolus in response to application of different concentrations of humic acids (HA) isolated from vermicompost. Corms were soaked for 24 hours in solutions containing $0,10,20,30$ and $40 \mathrm{mmol} \mathrm{L}^{-1}$ of C from HA. The corms were planted in 10- $\mathrm{dm}^{3}$ plastic bags filled with substrate and kept in a greenhouse. Growth of shoots and roots was evaluated. The results showed that the use of HA accelerates growth, and anticipates and increases flowering of Gladiolus.
\end{abstract}

Key words: Gladiolus L., organic matter, plant growth regulator, vegetative propagation, ornamental plants.

\section{RESUMO}

\section{Desenvolvimento do gladíolo em resposta ao tratamento dos bulbos com diferentes concen- trações de ácidos húmicos}

O gladíolo é uma planta ornamental para a produção de flores, cuja propagação é realizada por bulbos. A antecipação do florescimento e o aumento do número de botões florais, além da produção de bulbos comerciais, são problemas constantes a serem equacionados na cultura. A produção comercial de plantas ornamentais é tecnologicamente acelerada por meio de reguladores de crescimento. Dentre eles, vêm-se destacando as auxinas, hormônios vegetais com ação no enraizamento adventício e no alongamento celular. Alternativamente, as substâncias húmicas da matéria orgânica apresentam, também, efeito bioestimulante, muito semelhante ao efeito auxínico. Por essas razões, este trabalho teve como objetivo estudar o crescimento e desenvolvimento do gladíolo, em resposta à aplicação de diferentes concentrações de ácidos húmicos (AH), isolados de vermicomposto. Os bulbos foram imersos, por 24 horas, em soluções contendo 0, 10, 20,30 e $40 \mathrm{mmol} \mathrm{L}^{-1} \mathrm{de} C \mathrm{de} \mathrm{AH}$. Em seguida, foram plantados em sacolas plásticas de 10,0 dm³ contendo substrato e mantidos em casa de vegetação. Foram avaliadas características de crescimento da parte aérea e do sistema radicular. Os resultados obtidos permitiram concluir que o uso de AH acelera o crescimento, antecipa e aumenta a floração do gladíolo.

Palavras-chave: Gladiolus L., matéria orgânica, regulador de crescimento, propagação vegetativa, plantas ornamentais.

\footnotetext{
Received: 08/03/2012 - Accepted: 26/11/2012.

${ }^{1}$ Research funded by FAPEMIG (APQ 02395).

${ }^{2}$ Agronomist engineer. Doctor of Science. Instituto de Ciências Agrárias, Universidade Federal de Viçosa, Campus de F1orestal, Rodovia LMG 818, Km 06, 35690-000, Florestal, Minas Gerais, Brasil. marihus@ufv.br (corresponding author).

${ }^{3}$ Agronomist engineer. Doctor of Science. Instituto de Ciências Agrárias, Universidade Federal de Viçosa, Campus de Florestal, Rodovia LMG 818, km 06, 35690-000, Florestal, Minas Gerais, Brasil. lilian.estrela@ufv.br
}

Rev. Ceres, Viçosa, v. 60, n.1, p. 138-142, jan/fev, 2013 


\section{INTRODUCTION}

The world floriculture market is worth approximately US\$ 8 billion per year. Despite its potential economic importance, it is still little explored in Brazil, which accounts for only $2.5 \%$ of that amount, about US\$ 20 million. The Brazilian floriculture industry occupies an area of approximately 4,500 hectares (ha), including 700 ha under protected cultivation. The sector involves 5000 growers, largely concentrated in São Paulo, Rio de Janeiro and Minas Gerais, and 4000 retail shops (Faria, 2005; Baldotto et al., 2010; Barbosa, 2011).

Among the ornamental plants, Gladiolus (Gladiolus L.), also known as Sword lily, is a bulbous plant in the iris family (Iridaceae) originated from Africa. In Brazil, it has a high commercial demand especially for decorative arrangements. When about to bloom, the plant has over ten sword-shaped leaves. The name of the genus has origin from Latin, the diminutive of gladius, a sword (Lorenzi \& Souza, 2008; Barbosa, 2011). The commercial product is the inflorescence, which is a spike with 0.6 to $1.2 \mathrm{~m}$ in length, with 8 to 16 flowers placed in between a bract and a bracteole (Barbosa, 2011).

Gladiolus has short cycle (on average about 60 to 80 days) and provides a rapid financial return, which allow the cultivation in small areas. Plants can propagate asexually either from corms or cormlets, when for the production of cut flowers or new corms, respectively (Lorenzi \& Souza, 2008; Barbosa, 2011).

Even with strong demand, given the versatility in color, enabling many decorative uses, and even if Gladioli are commercially grown and with high technology, eg, in Holambra-SP, the induction of sprouting on corms, as well as standardization and increase in production of flowers and/or commercial corms are still bottlenecks for expansion of the crop-growing area. Furthermore, it is estimated that the production chain of flowers create each year about 500 thousand direct jobs and more than twice as indirect. The promising flower industry may be a potential option generating income for family farms. For this reason, the use of growth regulators becomes an important technology to achieve better performance in the activity (Barbosa, 2011). Oliveira (2009) pointed out that there is need for information on the use of growth regulators to increase yields in Gladiolus.

Humic acids (HA) induce rooting in many plants of agronomic interest (Canellas et al., 2006; Baldotto et al., 2009, 2010, 2011 and 2012). They also have stimulating effects on shoots, such as increases in leaf nutrient accumulation (Chen et al., 2004) and chlorophyll synthesis (Baldotto et al., 2009). Recent studies showed that HA stimulate the activity and synthesis of $\mathrm{H}^{+}$-ATPase enzymes in the plasma membrane of plant cells, similarly to the auxinic effect (Canellas et al. 2006). Synthetic auxins, known as plant growth regulators (Taiz \& Zeigher, 2003), are used on a commercial scale to promote rooting of ornamental plants (Vieira \& Castro, 2001; Lima et al., 2008). Application of HA, the bioactive fraction of the humified organic matter, to produce spikes and commercial corms, is another technological option. Studies indicate a concentration-dependent response to the action of HA in promoting growth and development of plants (Baldotto et al., 2009, 2010, 2011 and 2012). Therefore, studies that confirm the action of HA on the growth and development of ornamental plants and determine the maximum efficiency concentration can promote the diffusion of this new technology.

This work aimed to study the growth and development of Gladioli, in response to the treatment of corms, before planting, with solutions containing increasing concentrations of humic acids from vermicompost.

\section{MATERIAL AND METHODS}

Corms of variety White Friendship were purchased from CEASA in Contagem-MG, with uniform size (15.2 \pm $2.3 \mathrm{~cm}$ in circumference, $2.42 \pm 0.37 \mathrm{~cm}$ in diameter and $41.21 \pm 3.65 \mathrm{~g}$ of weight).

Humic acids were previously isolated and characterized by Baldotto et al. (2007). Treatments consisted of five concentrations $\left(0,10,20,30,40 \mathrm{mmol} \mathrm{L}^{-1} \mathrm{C}\right)$ of HA from vermicompost. Concentrations were similar to those used for Baldotto et al. (2009, 2010 and 2012). The concentration of $\mathrm{C}$ in the HA was $48.5 \mathrm{~kg} \mathrm{dag}^{-1}$. The corms were soaked in solutions of HA for 24 hours and, then, transferred to 10 $\mathrm{dm}^{3}$ plastic bags (radius and height of approximately 12.5 and $30 \mathrm{~cm}$, respectively) containing substrate in equal proportions of sand, subsurface soil and cattle manure, and kept in a greenhouse. Each experimental unit consisted of a container with one corm. All factors not combined in treatments such as light, irrigation, fertilization, etc., were controlled and kept constant (constant effect for all treatments) for all experimental units (Barbosa, 2011).

The experiment was conducted so that there was flowering and formation of new corms. The variables analyzed were: number of shoots (NS), number of leaves (NL); largest leaf length (LLL); largest leaf width (LLW), fresh weight of the longest leaf (FWLL), dry matter of longest leaf (DMLL), days to flowering (DF), number of inflorescences (NI) number of flower buds of first inflorescence (NBF), total number of corms produced (TNC), mean diameter of the corms produced (MDC), the total fresh mass of corms produced (TFMC) and mean fresh weight of corms produced (MFWC).

The experiment was conducted in a randomized block design with five replications. Results were subjected to 
analysis of variance and the effects of treatments for qualitative variables, were unfolded in mean contrasts. For the quantitative factors, regression equations were adjusted between the mean variables and the concentrations of HA. The application of the F test to the unfolding of the factors was performed at 10, 5 and $1 \%$ probability. In the regression analysis, the models were tested when the coefficient of determination was greater than 0.60 .

\section{RESULTS AND DISCUSSION}

The results showed that, in general, the Gladiolus plants derived from corms treated with humic acids showed increases, in absolute terms, in shoot growth and corm production compared with the control plants (Tables 1 and 2). For some key variables to assess the performance of Gladiolus, significant increases occurred as in the number of flower buds (NBF), with an increase of about $30 \%$. Moreover, flowering (DF) occurred on average four days earlier (Table 3). Both results show promising effects of the treatment of Gladiolus corms with humic acids.
There were significant increases in leaf length and leaf width (LLL and LLW) of plants treated with HA, indicating increased vegetative growth, which explains the greater number of flower buds in the spike (Table 3). The treatment of corms with HA led the quality of spikes to move from Class II (8-12 spikes), in the control, to Class I (12 to 16 spikes), according to standards by Veiling - Holambra,

Table 2. Means of growth characteristics of Gladiolus corms in response to the application of humic acid concentrations to corms before planting

\begin{tabular}{lcccc}
\hline & \multicolumn{3}{c}{ Growth characteristics of corms } \\
\cline { 2 - 5 } Treatments $^{\mathbf{1}}$ & TNC & $\begin{array}{c}\text { MDC } \\
\mathrm{cm}\end{array}$ & TFMC & MFWC \\
& 2.60 & 3.05 & 26.81 & $\mathrm{~g}$ \\
\hline$(-)$ & 2.40 & 3.54 & 31.36 & 13.35 \\
HA 10 & 2.20 & 3.57 & 28.22 & 13.83 \\
HA 20 & 2.75 & 3.73 & 31.54 & 13.29 \\
HA 30 & 3.60 & 3.54 & 43.48 & 12.14 \\
HA 40 &
\end{tabular}

${ }^{1}$ Trataments: (-) $10 \mathrm{HA}, 20 \mathrm{HA}, 30 \mathrm{HA}, 40 \mathrm{HA}$; humic acids in the concentrations $0,10,20,30$ and $40 \mathrm{mmol} \mathrm{L}^{-1}$ of C. ${ }^{2}$ Characteristics of corms: TNC, the total number of corms; MDC, mean diameter of the corms; TFMC, the total fresh mass of corms; and MFWC, mean fresh weight of corms.

Table 1. Means of growth characteristics of Gladiolus shoots in response to the application of humic acid concentrations to corms before planting

\begin{tabular}{lccccccccc}
\hline & \multicolumn{8}{c}{ Growth characteristics of shoots $^{2}$} \\
\cline { 2 - 11 } Treatments $^{1}$ & $\mathbf{N S}$ & TLN & $\begin{array}{c}\text { UL } \\
\text { cm }\end{array}$ & $\begin{array}{c}\text { LLW } \\
\text { cm }\end{array}$ & $\begin{array}{c}\text { FWLL } \\
\text { g }\end{array}$ & $\begin{array}{c}\text { DMLL } \\
\text { g }\end{array}$ & DF & NI & NBF \\
\hline$(-)$ & 2.6 & 11.0 & 77.9 & 3.36 & 3.54 & 0.62 & 74.0 & 1.8 & 9.2 \\
HA 10 & 2.6 & 12.6 & 89.6 & 3.68 & 3.15 & 0.59 & 68.4 & 2.0 & 12.2 \\
HA 20 & 2.4 & 11.6 & 84.4 & 3.94 & 4.17 & 0.69 & 69.6 & 2.0 & 12.0 \\
HA 30 & 2.6 & 13.0 & 87.3 & 3.70 & 3.68 & 0.64 & 69.0 & 1.8 & 12.0 \\
HA 40 & 3.6 & 17.2 & 83.4 & 3.70 & 3.22 & 0.61 & 71.2 & 2.6 & 11.2 \\
\hline
\end{tabular}

${ }^{1}$ Trataments: (-), $10 \mathrm{HA}, 20 \mathrm{HA}, 30 \mathrm{HA}, 40 \mathrm{HA}$; humic acids in the concentrations 0, 10, 20, 30 and $40 \mathrm{mmol} \mathrm{L}^{-1}$ of C. ${ }^{2} \mathrm{Characteristics}$ of shoot growth: NS, number of shoots; TNL, total number of leaves; LLL, largest leaf length; LLW, largest leaf width; FWLL, fresh weight of longest leaf; DMLL, dry matter of longest leaf; DF, days to flowering; NI, number of inflorescences; NBF, number of flower buds of first inflorescence.

Table 3. Mean contrast, relative increase (RI), mean square error (MSE) and coefficient of variation (CV) of the growth characteristics of Gladiolus shoots in response to application of humic acid concentrations in the corms before planting

\begin{tabular}{|c|c|c|c|c|c|c|c|c|c|c|}
\hline \multirow{3}{*}{ SV } & \multirow{3}{*}{ DF } & \multicolumn{9}{|c|}{ Mean contrast $^{1}$ and relative increase ${ }^{2}$} \\
\hline & & \multicolumn{9}{|c|}{ Growth characteristics of shoots ${ }^{3}$} \\
\hline & & NS & TLN & $\begin{array}{c}\mathbf{U L} \\
\mathrm{cm}\end{array}$ & $\begin{array}{c}\mathbf{L W W} \\
\mathrm{cm}\end{array}$ & $\begin{array}{c}\text { FWLL } \\
\mathrm{g}\end{array}$ & $\begin{array}{c}\text { DMLL } \\
\mathrm{g}\end{array}$ & DF & NI & NBF \\
\hline$(-) v s \mathrm{HA}$ & 1 & 0.20 & 2.60 & $8.29^{\circ}$ & $0.40^{\circ}$ & 0.01 & 0.01 & $-4.45^{*}$ & 0.30 & $2.65 * *$ \\
\hline $\mathrm{RI}(\%)$ & & 7.69 & 23.64 & 10.64 & 11.76 & 0.31 & 1.04 & 6.01 & 16.67 & 28.80 \\
\hline MSE & 20 & 1.00 & 16.16 & 72.41 & 0.17 & 0.86 & 0.02 & 13.86 & 1.14 & 3.32 \\
\hline $\mathrm{CV}(\%)$ & & 36.23 & 30.73 & 10.06 & 11.33 & 26.09 & 20.47 & 5.28 & 52.33 & 16.09 \\
\hline
\end{tabular}

${ }^{1}$ Mean contrast: (-) vs. HA, mean contrast between control $\left(0 \mathrm{mmol} \mathrm{L}^{-1} \mathrm{C}\right.$ of HA) versus humic acid in concentrations of $10,20,30$ and $40 \mathrm{mmol} \mathrm{L}^{-1}$ of C. ${ }^{2}$ Relative increase: $100(\mathrm{x}-\mathrm{y}) / \mathrm{y}$, where $\mathrm{x}$ is the highest mean of the treatment and $\mathrm{y}$ the lowest mean of the treatment. ${ }^{3}$ Characteristics of shoot growth: NS, number of shoots; TNL, total number of leaves; LLL, largest leaf length; LLW, largest leaf width; FWLL, fresh weight of longest leaf; DMLL, dry matter of longest leaf; DF, days to flowering; NI, number of inflorescences; NBF, number

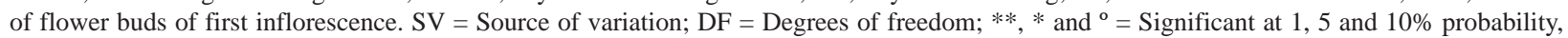
respectively. 
reflecting a significant improvement in the commercial standard. The results indicate that these treatments can also result in technology for the production of commercial corms.

The regression equations, which were fitted between the dependent variables and the biostimulant concentrations (Table 5), followed the quadratic (six) and square root (five) models, with only two unfitted variables represented by the means. These two models were the most representative of the plant responses to different concentrations of HA.

Table 4. Mean contrast, relative increase (RI), mean square error (MSE) and coefficient of variation (CV) of the growth characteristics of Gladiolus corms in response to application of humic acid concentrations in the corms before planting

\begin{tabular}{|c|c|c|c|c|c|}
\hline \multirow{3}{*}{ SV } & \multirow{3}{*}{ DF } & \multirow{2}{*}{\multicolumn{4}{|c|}{$\begin{array}{c}\text { Mean contrast }{ }^{1} \text { and relative increase } \\
\text { Growth characteristics of corms } \\
\end{array}$}} \\
\hline & & & & & \\
\hline & & TNC & $\begin{array}{c}\text { MDC } \\
\mathbf{c m}\end{array}$ & $\begin{array}{c}\text { TFMC } \\
\mathrm{g}\end{array}$ & $\begin{array}{c}\text { MFWC } \\
\mathrm{g}\end{array}$ \\
\hline$(-) v s \mathrm{HA}$ & 1 & 0.14 & 0.54 & 6.84 & 3.95 \\
\hline $\operatorname{IR}(\%)$ & & 5.29 & 17.79 & 25.49 & 42.90 \\
\hline MSE & 20 & 0.78 & 0.59 & 334.33 & 49.18 \\
\hline $\mathrm{CV}(\%)$ & & 32.95 & 21.97 & 57.23 & 57.04 \\
\hline
\end{tabular}

${ }^{1}$ Mean contrast: (-) vs. HA, mean contrast between control $(0 \mathrm{mmol}$ $\mathrm{L}^{-1} \mathrm{C}$ of HA) versus humic acid in concentrations of $10,20,30$ and $40 \mathrm{mmol} \mathrm{L}^{-1}$ of C. ${ }^{2}$ Relative increase: $100(\mathrm{x}-\mathrm{y}) / \mathrm{y}$, where $\mathrm{x}$ is the highest mean of the treatment and $y$ the lowest mean of the treatment. ${ }^{3}$ Characteristics of corms: TNC, the total number of corms; MDC, mean diameter of the corms; TFMC, the total fresh mass of corms; and MFWC, mean fresh weight of corms. SV = Source of variation; DF $=$ Degrees of freedom.

Table 5. Regression equations for the growth characteristics of shoot and corms of Gladiolus in response to application of humic acid concentrations to corms before planting

\begin{tabular}{llc}
\hline Variable $^{1}$ & \multicolumn{1}{c}{ Regression equation } & $\mathbf{R}^{2}$ \\
\hline NS & $\hat{y}=2.70-0.05 \mathrm{x}+0.002^{\circ} \mathrm{x}^{2}$ & 0.8897 \\
TNL & $\hat{y}=11.61-0.09 \mathrm{x}+0.005^{(\mathrm{P}<0.13)} \mathrm{x}^{2}$ & 0.8643 \\
LLL $(\mathrm{cm})$ & $\hat{y}=78.14+5.19^{\circ} \mathrm{x}^{0.5}-0.69 \mathrm{x}$ & 0.7977 \\
LLW $(\mathrm{cm})$ & $\hat{y}=3.37+0.04 \mathrm{x}-0.0008^{\circ} \mathrm{x}^{2}$ & 0.8308 \\
FWLL $(\mathrm{g})$ & $\hat{y}=\bar{y}=3.56$ & 0.8214 \\
DMLL $(\mathrm{g})$ & $\hat{y}=\bar{y}=0.63$ & 0.8012 \\
DF & $\hat{y}=73.97-2.83^{*} \mathrm{x}^{0.5}+0.37 \mathrm{x}$ & 0.9364 \\
NI & $\hat{y}=1.90-0.01 \mathrm{x}+0.00071^{(\mathrm{P}<0.22)} \mathrm{x}^{2}$ & 0.6190 \\
NBF & $\hat{y}=9.21+1.51^{* *} \mathrm{x}^{0.5}-0.19 \mathrm{x}$ & 0.9875 \\
TNC & $\hat{y}=2.65-0.06 \mathrm{x}+0.002^{* *} \mathrm{x}^{2}$ & 0.9746 \\
MDC $(\mathrm{cm})$ & $\hat{y}=3.05+0.22^{*} \mathrm{x}^{0.5}-0.022 \mathrm{x}$ & 0.9373 \\
TFMC $(\mathrm{g})$ & $\hat{y}=28.61-0.27 \mathrm{x}+0.01^{(\mathrm{P}<0.14)} \mathrm{x}^{2}$ & 0.8348 \\
MFWC $(\mathrm{g})$ & $\hat{y}=9.17+2.27 * * \mathrm{x}^{0.5}-0.28 \mathrm{x}$ & 0.9937 \\
\hline
\end{tabular}

${ }^{1}$ Variable: NS, number of shoots; TNL, total number of leaves; LLL, largest leaf length; LLW, largest leaf width; FWLL, fresh weight of longest leaf; DMLL, dry matter of longest leaf; DF, days to flowering; NI, number of inflorescences; NBF, number of flower buds of first inflorescence; TNC, the total number of corms; MDC, mean diameter of the corms; TFMC, the total fresh mass of corms; and MFWC, mean fresh weight of corms. $* *, *$ and $^{\circ}=$ Significant at 1 , 5 and $10 \%$ probability, respectively.
The variable chosen to identify the concentration of the biostimulant solution of maximum physical efficiency (MPE) was the number of flower buds (NBF), which is directly proportional to the quality of the commercial product (Barbosa, 2011), and the concentration was 15.58 mmol L ${ }^{-1} \mathrm{C}$ of HA. The other variables were estimated (Table 6) using this concentration at the point of maximum MFWC and the regression equations of Table 5. In the last three columns of Table 6 , the means of the controls for each variable can be compared with those obtained with the most efficient concentration of the biostimulant and also the percentage differences.

Application of HA isolated from vermicompost favored the extrusion of organic acids by the roots of maize seedlings, as reported by Canellas et al. (2008). When in contact with the acidified environment the rhizosphere, the particles of HA can break and generate subunits that can change the cell metabolism through activation of $\mathrm{H}^{+}$-ATPases in the plasma membrane of root cells (Façanha et al., 2002; Canellas et al. 2006). These mechanisms lead to acidification of the apoplast and the activation of cell wall degrading exoenzymes, making it more susceptible to the vacuolar turgor pressure and,

Table 6. Means of growth characteristics under the concentration of maximum physical efficiency $(\mathrm{MPE}$ concentration $=16.48$ mmol L ${ }^{-1} \mathrm{C}$ of $\mathrm{HA}$ ) for the chosen variable mean fresh weight of corms (MFWC) in response to humic acids isolated from vermicompost applied in five concentrations $(0,10,20,30,40$ $\mathrm{mmol} \mathrm{L} \mathrm{L}^{-1} \mathrm{C}$ of $\mathrm{HA}$ ) to the corms before planting

\begin{tabular}{lccc}
\hline Variable $^{1}$ & $\begin{array}{c}\text { Control } \\
\text { mean }\end{array}$ & $\begin{array}{c}\text { MPE } \\
\text { mean }\end{array}$ & $\begin{array}{c}\text { Percentage } \\
\text { difference }^{2}\end{array}$ \\
\hline NBF & 9.2 & 12.2 & 33 \\
NS & 2.6 & 3.10 & 19 \\
TNL & 11.0 & 11.4 & 4 \\
LLL $(\mathrm{cm})$ & 77.9 & 87.9 & 13 \\
LLW $(\mathrm{cm})$ & 3.36 & 3.80 & 13 \\
FWLL $(\mathrm{g})$ & 3.54 & $\mathrm{nd}$ & 9 \\
DMLL $(\mathrm{g})$ & 0.62 & $\mathrm{nd}$ & 3 \\
DF & 74.0 & 68.6 & -8 \\
NI & 1.8 & 1.9 & 6 \\
TNC & 2.60 & 2.20 & -18 \\
MDC $(\mathrm{cm})$ & 3.05 & 3.58 & 17 \\
TFMC $(\mathrm{g})$ & 26.81 & 26.83 & 0 \\
MFWC $(\mathrm{g})$ & 9.20 & 13.77 & 50 \\
\hline
\end{tabular}

${ }^{1}$ Variable: MFWC, mean fresh weight of corms (chosen to identify the concentration of MPE); NS, number of shoots; TNL, total number of leaves; LLL, largest leaf length; LLW, largest leaf width; FWLL, fresh weight of longest leaf; DMLL, dry matter of longest leaf; DF, days to flowering; NI, number of inflorescences; NBF, number of flower buds of first inflorescence; TNC, the total number of corms; MDC, mean diameter of the corms; TFMC, the total fresh mass of corms; and; ${ }^{2}$ Percentage differences: $100(x-y) / y$, where $\mathrm{x}$ is the highest mean of the treatment and $\mathrm{y}$ the lowest mean of the treatment, considering the control means and the MPE mean that appear in the first two columns of this table; nd $=$ not determined because of lack of fit. 
consequently, to cell elongation. This may explain the effect promoted by HA, increasing growth and providing a greater and earlier flowering of Gladiolus.

The positive effects on the development of Gladiolus indicated the technological potential of the humic acids, after the adjustment of the biostimulant concentrations to other bulbous plants, since the empirical use could result in increased or decreased efficiency of the plants, while the development of science-based criteria can ensure the optimization of the effect of these substances.

\section{CONCLUSIONS}

The growth response of Gladiolus to the treatment of corms with HA, mostly with quadratic and square root increases, confirmed the hypothesis of the biostimulant effect of these substances.

The application of HA $\left(15.58 \mathrm{mmol} \mathrm{L}^{-1} \mathrm{C}\right)$ to Gladiolus corms before planting accelerated growth, anticipated and increased flowering.

The commercial quality of Gladiolus floral spikes increased with the treatment of corns with HA before planting.

\section{ACKNOWLEDGEMENTS}

This work was funded by FAPEMIG (APQ-02395). The authors thank the students, staff and professors of the Campus Florestal-UFV for the contribution to this project, especially Dirce Maria Lago Bezerra, who assisted in the purchase of the Gladiolus corms.

\section{REFERENCES}

Barbosa JG (2011) Palma-de-Santa-Rita (Gladíolo) Produção comercial de flores e bulbos. Viçosa, Editora UFV. 113p.

Baldotto LEB, Baldotto MA, Giro VB, Canellas LP, Olivares FL \& Bressan-Smith R (2009) Desempenho do abacaxizeiro 'Vitória' em resposta à aplicação de ácidos húmicos durante aclimatação. Revista Brasileira de Ciência do Solo, 33:979. 990 .

Baldotto LEB, Baldotto MA, Canellas LP, Bressan-Smith R \& Olivares FL (2010) Growth promotion of pineapple 'Vitória' by humic acids and Burkholderia spp. during acclimatization. Revista Brasileira de Ciência do Solo, 34:1593-1600.

Baldotto LEB, Baldotto MA, Soares RR, Martinez HEP \& Venegas VHA (2012) Adventitious rooting in cuttings of croton and hibiscus in response to indolbutyric acid and humic acid. Revista Ceres, 59:476-483.

Baldotto MA, Canellas LP, Canela MC, Simões ML, Martin-Neto L, Fontes MPF \& Velloso ACX (2007) Propriedades redox e grupos funcionais de ácidos húmicos isolados de adubos orgânicos. Revista Brasileira de Ciência do Solo, 31:465-475.

Baldotto MA, Muniz RC, Baldotto LEB \& Dobbss LB (2011) Root growth of Arabidopsis thaliana (L.) Heynh. treated with humic acids isolated from typical soils of Rio de Janeiro state, Brazil. Revista Ceres, 58:504-511.
Canellas LP, Zandonadi DB, Olivares FL \& Façanha AR (2006) Efeitos fisiológicos de substâncias húmicas - o estímulo às $\mathrm{H}^{+}$ATPases. In: Fernandes MS (Ed.) Nutrição Mineral de Plantas. Viçosa, Sociedade Brasileira de Ciência do Solo. p.175-200.

Canellas LP, Teixeira Junior LRL, Dobbss LB, Silva CA, Medici LO, Zandonadi DB \& Façanha AR (2008) Humic acids cross interactions with root and organic acids. Annals of Applied Biology, 1:01-10.

Chen Y, Clapp CE \& Magen H (2004) Mechanisms of plant growth stimulation by humic substances: The role of organo-iron complexes. Soil Science Plant Nutricion, 50:1089-1095.

Faria RT (2005) Floricultura: as plantas ornamentais como agronegócio. Londrina, Editora Mercenas. 116p.

Façanha AR, Façanha ALO, Olivares FL, Guridi F, Santos GA, Velloso ACX, Rumjanek VM, Brasil F, Schripsema J, Braz-Filho R, Oliveira MA \& Canellas LP (2002) Bioatividade de ácidos húmicos: Efeito sobre o desenvolvimento radicular e sobre a bomba de prótons da membrana plasmática. Pesquisa Agropecuária Brasileira, 37:1301-1310.

Lima DM, Silva CL, Ritter M, Biasi LA, Zanette F \& ZuffellatoRibas KC (2008) Substratos e auxinas no enraizamento de estacas caulinares de espinheira-santa. Scientia Agraria, 9:85-89.

Lorenzi HE \& Souza HM (2008) Plantas ornamentais no Brasil: arbustivas, herbáceas e trepadeiras. $4^{\text {a }}$ ed. Nova Odessa, Instituto Plantarum. $1088 \mathrm{p}$.

Oliveira LL (2009) Produção de gladíolo em função da aplicação de nitrogênio e ethiltrinezapac. Dissertação de Mestrado. Universidade Estadual Paulista, Ilha Solteira. 43p.

Taiz L \& Zeiger E (2003) Fisiologia vegetal. $3^{\mathrm{a}}$ ed. Porto Alegre, Artmed. 719p

Vieira EL \& Castro PRC (2001) Ação de bioestimulante na germinação de sementes, vigor das plântulas, crescimento radicular e produtividade de soja. Revista Brasileira de Sementes, 23:222228. 